\title{
Models of Democracy and the Design of Slovenian Political Party Web Sites
}

\author{
Simon Delakorda \\ Faculty of Social Sciences, University of Ljubljana, Slovenia, \\ simon.delakorda@guest.arnes.si
}

\begin{abstract}
Web sites of Slovenian political parties do not fully exploit the Internet's potential for interactive and deliberative communication on political issues with citizens, because they favour a competitive-elitist perception of democracy. As result, political party's web sites are mainly used for political mobilization, agitation in persuasion. Supporting this model of democracy via web pages enables political parties to strengthen their position of power and control in decision-making process, to legitimise a hegemonic position of representative democracy within political system, to impose the perception of citizens as consumers of political information and to provide democratic legitimization for capitalist mode of production. In order to strengthen citizen's e-participation on political issues, a conceptual shift in designing political party's web sites according to participatory and deliberative model of democracy is needed.
\end{abstract}

Keywords: Political parties, Web sites, Electronic democracy, Citizens, Slovenia

\section{Introduction}

There is a wide recognition among authors that Internet is playing an increasingly important role in party politics [Vreg, 2000; Selm, Jankowski and Tsaliki, 2001; Norris, 2003; Gibson, Lusoli and Ward, 2003]. Political parties in western democracies have recognized the importance of Internet technology in improving their communication strategies, political mobilization and information delivery. On the other hand, many authors argue [Nixon and Johansson, 1998; Becker and Slaton, 2000; Franz, 2000] that the web sites of political parties do not fully exploit the potential of the Internet for participatory means. Although different authors provide different explanations for this phenomena (e.g., balance of power, lack of interest,

Please use the following format when citing this chapter:

Delakorda, S., 2006, in IFIP International Federation for Information Processing, Volume 223, Social Informatics: An Information Society for All? In Remembrance of Rob Kling, eds. Berleur, J., Numinen, M. I., Impagliazzo, J., (Boston Springer), pp. 279-295 
lack of knowledge and resources, fear of mass participation, strive for control), a substantial amount of the existing analysis [Vreg, 2000; Nixon and Johansson, 1998] lacks theoretical background that would help to explain why political parties are not prone to use the Internet to stimulate interactive political communication with citizens on public issues.

My underlying assumption is that web sites of Slovenian political parties do not fully exploit the Internet's potential for interactive communication because they favour an elitist-competitive perception of democracy. This perception emphasizes central role of political parties and leaders and recognises elections of representatives as the most important operation of political system [Van Dijk, 1996:48]. Political parties are perceived as intermediates between state and citizens, as the main actor during elections, as important factor in the process of political socialization and as formal executive control over decision-making and formulation of public policy [Della Porta, 2003: 120-121]. Those functions are in line with a representative type of democracy, which according to Van Dijk (ibid.) does not favour wider and direct participation of electorate in decision-making process. Therefore, supporting an elitist-competitive model of democracy via Internet communication and web pages enables political parties to strengthen their position of power and control in democratic process, to legitimize hegemonic position of representative democracy within political systems and to impose the perception of citizens as consumers of political information. What is more, political parties are forced to reproduce this model of democracy in order to provide democratic legitimization for capitalist mode of production [Offe, 1988: 59-61]. As a result, there is little reason for political parties to promote participation and deliberative democracy [Perczynski, 2003] via Internet communication.

On the other hand, a substantial amount of academic analysis is concerned with the democratic deficit of the present form of democracy in Slovenia [Bernik, 2002; Makarovic, 2002; Vodopivec et al., 2002]. Most important causes for the decline of political participation by citizens in Slovenia are: consolidation of representative democracy, instrumental understanding of democracy and relatively satisfactory economic and social situation [Makarovic, 2002: 77-84]. On the other hand, problems with political party's arrogance, clientelism, and ambition to regulate public life (centralization and hierarchy) are resulting in lower quality of governance and stressing the need for more direct democracy [Rus, 2002: 25]. Combining with traditional rejection of their mobilization role by Slovenian citizens, political parties rate among the least trustful institutions in Slovenia. One way to deal with representative democratic deficit (i.e. strengthen legitimacy of political parties) in western political systems is by enriching public debate on political issues and by allowing citizens to directly participate in democratic decision-making using Internet technology (parties web sites) [Fishkin, 2000]. In that manner Nixon and Johansson (1998: 135) are using the term discursive democracy to describe discussion and interaction between individual citizens that may support more consensual forms of decision-making. It implies an engagement or involvement in politics that refutes the notion of a passive consumption of 'top down' delivered political views, in favour of »bottom up« discursive interaction in which citizens not only consume, but also play, 
a part in the creation of politics. Those ideas were implemented in various concepts of electronic, digital, cyber and teledemocracy [Grossman, 1995; Hagen, 1996; Tsagarousianou, 1998; Becker and Slaton, 2000; Hague and Loader; 2001].

My basic intention in this paper is to provide limited empirical contribution to existing interpretation of political science web sites analyses in what I call an e-party dilemma - improving political party's web sites information delivery but not improving citizen's e-participation in decision making. Slovenian political party's web sites will be analysed in terms of various e-democracy techniques they provide in order to enable interactive in inclusive online communication with citizens on public issues. Frequency and type of different e-democracy techniques will examine my assumption whether Slovenian political party's web sites are designed according to elitist-competitive democracy or not. This will further lead to conclusion whether the one way communication flow of web sites contributes to reduction of the democratic deficit of representative democracy in Slovenia and how the web sites should be conceptually improved in order to enrich public debate on political issues by allowing them to directly participate in democratic decision-making.

\section{Theoretical Framework}

\subsection{Models of Political Democracy}

In order to establish proper operational framework for empirical web sites analysis, I created an analytical model combining Van Dijk's typology of political democracy with Trechsel's typology of e-democracy techniques (see Chapter 3 for more details).

Jan A.G. M. van Dijk [1996: 47-52] draws very clear links between the models of democracy and ICT (information-communication technology) usage for strengthening citizen's participation. Van Dijk distinguishes among five models of democracy and their distinctive understanding of e-participation: legalist democracy, competitive democracy, plebiscitary democracy, pluralist democracy and participatory democracy ${ }^{1}$.

\subsubsection{Competitive-Elitist Model of Democracy}

In this model, the use of ICT instruments is focused on elections and information campaigns. Political elites directly address selected target groups of voters via one way mass and modern public information systems that relay differentiated political messages. The interested public, which is understood as a fragmented electoral body of political leaders and parties, must have access to the information, views, opinions and conduct of its elected leaders and representatives. Other ICT instruments intended for conversation and registration (debate forums, e-conferences) are used only if they are of benefit to the political leadership. The use of these instruments can be misleading, because it can make us believe that the model in question is direct democracy, which is not true. 


\subsubsection{Legal Model of Democracy}

From the point of view of legal model, the role of ICT in a political system is limited to remedying the fundamental problem of the existing political system - information deficit. Information deficit is generated at three levels: information shortage of the political system caused by bureaucratic barriers, an insufficient flow of information between the government/administration and citizens and unsuitable information distribution resulting in difficult situation in the system of checks and balances. ICT is used to tackle an information deficit by means of a computer-supported information systems, information centres, public services and computer-supported enquiries by citizens. These aplications facilitate greater transparency in the functioning of the political system, which should tackle the problem of information complexity and shortage. The ICT instruments that are rejected or not trusted are ereferendums, e-debates among citizens and e-conferences.

\subsubsection{Pluralist Model of Democracy}

Two ICT features are relevant for this model of democracy: 1) a multiple political information chanells and debate systems that allow conversation within an organisation and between an organisation and citizens; 2) access to interactive communication networks that support the network concept of politics. Consequently, ICT systems are used within and among civil society organisations to establish databases, to voice opinion and take part in the debate. In addition mass and public information systems, registering systems and various computer-supported lists and reviews of organisations and institutions are generated. The preferred ICT instruments are e-mail, discussion lists, teleconferences and support systems for debates on both complex issues.

\subsubsection{Plebiscitary Model of Democracy}

This model favours establishment of direct democracy in a large and complex societies (teledemocracy). Decision-making in a political system was to be replaced with a constant registration of the will of individual citizens. Consequently, registration systems of elections and opinions (tele-elections, referendums and eassemblies) of citizens are favoured. To these are occasionally added conversation instruments, such as electronic town halls, teleconferences, etc. Even consultation instruments are not ignored, facilitating communication between citizens and mass and public information systems. Information delivery instruments and those that are controlled by institutional politics are mistrusted.

\subsubsection{Participatory model of democracy}

ICT instruments that can offer information and support for citizen activism are central. Computerised information campaigns and public information systems must be suitably structured and accessible all in order to open up the political system and make its functioning transparently. User-friendly new media and electronic discussion instruments are tools for opinion forming, learning and active participation. Notice-board lists in computer networks, teleconferences and electronic town halls are only welcome in the participatory model if participatory 
processes are not reserved for social and intellectual elites and if they are designed to suit discussion instruments.

\section{2 eDemocracy Techniques}

Alexandre H. Trechsel [2002: 43] defines e-democracy as "all electronic means of communication that enable/empower citizens in their efforts to hold rulers/politicians accountable for their actions in the public realm. Depending on the aspect of democracy being promoted, e-democracy can employ different techniques: (1) for increasing the transparency of the political process; (2) for enhancing the direct involvement and participation of citizens; and, (3) improving the quality of opinion formation by opening new spaces of information and deliberation."

Trechsel (2002: 45-51) defines each technique further as:

\subsubsection{Techniques for Increasing Transparency}

Basically it refers to e-access, defined as the use of the Internet to improve electronic access to official documents and to political information that will enhance the transparency of the political process and the quality of opinion formation leading to a greater political involvement of citizens.

\subsubsection{Techniques for increasing participation}

They include applications of e-consultation, e-petition, e-polling and e-voting. $E$ consultation refers to the use of the Internet to disseminate to the wider public, experts and interest groups developments in a policy field and invite them to respond. E-petition uses the Internet to enable citizens to initiate a petition on a public issue, invite others to signal their support and finally submit their petition. $E$ polling refers to the use of the Internet for providing citizens (or a sample thereof) with a tool that allows them to express their opinions on a public issue and to measure public opinion. E-voting can be separated in two models. The first model simply replaces existing paper ballots with a machine that records votes locally then transfers those votes via the Internet to election headquarters. In the second model voters are offered the possibility of voting from any terminal or computer connected to the Internet to cast their vote. E-voting can be further distinguish between $e$ referendum, where citizens are offered to vote online on a specific public issue to be adopted and e-election which relates to the use of the Internet for casting a ballot that is transmitted to electoral officials via the Internet. In the case of e-elections within parties, e.g. for primaries or for electing party leaders, the vote is transmitted via the Internet to party officials.

\subsubsection{Techniques for Promoting New Spaces of Deliberation}

Are focusing on the development of an e-forum. This e-technique provides citizens with an online tool that allows them to exchange and share respective political opinions among themselves. The aspiration of e-democracy advocates is that eforums will enhance the process of citizen's opinion formation through their deliberative engagement. 


\section{Analytical Model}

A distinctive connection between Van Dijk's models of political democracy and Trechsel's e-democracy techniques can be illustrated by table 1:

This disposition will be used as an analytical model for analysing Slovenian political party's web sites. For example: if a certain Slovenian political party web site employs e-democracy techniques of e-access, e-poll and e-voting, it would mean, that the web site is conceptually designed according to competitive-elitist model of democracy. And opposite, if a web site employs techniques of e-petition, eforum and e-consultation, it would mean that the web site is based on participatory model of democracy. In case, party's web site employs combination of various edemocracy techniques, this would suggest that the web site is designed according to various models of democracy.

Table 1. E-democracy techniques favoured by models of political democracy

\begin{tabular}{|c|c|c|c|c|c|c|}
\hline & & \multirow[b]{2}{*}{$\begin{array}{c}\text { Elitist- } \\
\text { competitive }\end{array}$} & \multicolumn{4}{|c|}{ Models of democracy } \\
\hline & & & Legalist & Pluralist & Plebiscitary & Participatory \\
\hline \multirow{7}{*}{ 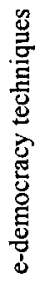 } & e-access & & $\mathrm{x}$ & $\mathbf{x}$ & $\mathrm{x}$ & $\mathrm{x}$ \\
\hline & e-petition & & & & $\mathrm{x}$ & $\mathrm{x}$ \\
\hline & e-consultation & $\mathrm{x}$ & $\mathrm{x}$ & $\mathrm{x}$ & & $\mathrm{x}$ \\
\hline & e-voting & $\mathrm{x}$ & & & $\mathbf{x}$ & \\
\hline & e-referendum & & & & $x$ & \\
\hline & e-forum & $\mathrm{x}$ & & $x$ & & $\mathrm{x}$ \\
\hline & e-poll & $\mathrm{x}$ & $\mathrm{x}$ & & $\mathrm{x}$ & \\
\hline
\end{tabular}

\section{Empirical Analysis}

\subsection{Analysis of Slovenian Political Parties Web Sites}

Empirical analysis consists of three stages. At the first stage I used web browsers to identify the 'Universe' of the web sites of registered Slovenian political parties. At the second stage instrumental analysis of electronic democracy techniques was conducted on identified political party's websites as suggested by analytical model. In final stage of empirical research, collected data were analysed in order to test research assumptions raised in this paper. 


\subsection{Identifying the Registered Slovenian Political Parties}

According to the official list of registered political parties ${ }^{2}$ held by Ministry of Internal Affairs of Republic of Slovenia (MNZ RS) ${ }^{3}, 39$ political parties were registered in Slovenia on 12.7.2004. Of which there are 8 parties that constitute present National assembly (parliament) and 31 parties that are non parliamentary.

By using combination of Slovenian search engines www.najdi.si, www.slowwwenia.com and www.matkurja.com/ we were able to identify 22 political parties' websites out of 39.8 of them belong to parliamentary and 14 belong to registered political parties (see Appendix for more details). One registered political party website was not accessible. This means that $56 \%$ of registered political parties in Slovenia have their own web site. As a result the 'universe' of registered Slovenian political party's web sites consists of 21 sites (Table no. 2).

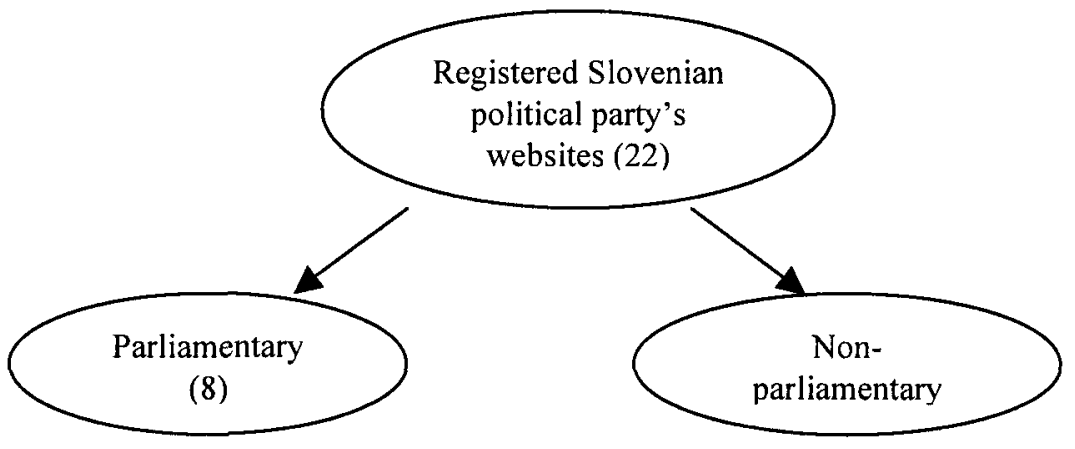

Figure 1 The 'universe' of Slovenian political party's websites as located by web browsers www.najdi.si, www.slowwwenia.com and www.matkurja.com/ during $15^{\text {th }}-18^{\text {th }}$ of March 2004 and supplemented on $27^{\text {th }}$ of July 2004.

\subsection{Frequency and Types of Electronic Democracy Techniques}

Analysis of e-democracy techniques, as suggested by analytical model, was conducted on 21 web sites since one was no accessible. Tables, 2, 3 and 4 are presenting the performed analysis.

Table 2 shows that all political parties with web sites provided kind of information on party activities, members, issues, events etc. Less than half of web sites provided e-poll ${ }^{4}$ application on current political issues and standings. One third of web sites also had e-forum ${ }^{5}$ application, which enables users to express their positions, comments and standing on certain political issues. 
Table 2. Frequency of provided on Slovenian political parties web sites

\begin{tabular}{|c|c|c|c|c|c|c|c|}
\hline 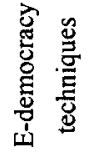 & e-access & e-poll & e-petition & e-forum & $\begin{array}{c}\mathrm{e}- \\
\text { consultatio } \\
\mathrm{n}\end{array}$ & e-election & $\begin{array}{c}\text { e- } \\
\text { referendu } \\
\text { m }\end{array}$ \\
\hline 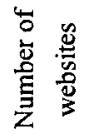 & 21 & 9 & none & 7 & none & none & none \\
\hline
\end{tabular}

Slovenian political party's web sites do not hold e-petition, e-consultation, eelection and e-referendum applications. Those e-democracy techniques are currently not available to Slovenian Internet users.

Table 3. E-Democracy Tolls Comparison Between Parliamentary and Non Parliamentary Political Party's Web Sites

\begin{tabular}{|c|c|c|c|c|c|c|c|}
\hline & e-access & e-poll & e-petition & e-forum & $\begin{array}{c}\mathrm{e}- \\
\text { consultatio } \\
\mathrm{n}\end{array}$ & e-election & $\begin{array}{c}\text { e- } \\
\text { referendu } \\
\mathrm{m}\end{array}$ \\
\hline 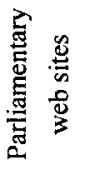 & 8 & 6 & none & 4 & none & none & none \\
\hline 总 & 13 & 3 & none & 3 & none & none & none \\
\hline
\end{tabular}

Based on empirical frequency of e-democracy tolls provided by Slovenian political party's web sites, it is safe to claim that parties are not using all participatory possibilities provided by Internet technology. As noted, they focus mainly on policy information delivery, issues promotion, campaigning, presenting party leaders activities etc. As result, e-access tool is most common web sites application. On the other hand, interactive communication with publics and citizens is facing serious deficiency. Although web sites provide very simple e-polling and eforum applications to some degree, they use in traditional way. Consequently eforums do not enable deliberative, moderated and focused conversation on political issues that would create qualitative public opinion. Similar case is with e-polls, 
which provide no representative and deliberative public opinion on often trivial political issues (expressing party support, evaluating political decision made by political authorities etc).

As noticed, web sites are clearly missing participatory e-democracy techniques such as e-consultation and e-petition, which would enable party members, and voters to direct influence party politics, programmes, policy and law proposals. Same counts for plebiscitary e-democracy applications such as e-voting or e-referendum.

Comparing parliamentary and non parliamentary political parties e-democracy application frequency on their respective web sites it is clear that parliamentary actors are putting greater emphasis concerning information and communication performance and activities. Most of parliamentary parties have e-poll application in contrast to less than third of non-parliamentary. Half of parliamentary parties have eforum application in contrast to less than of non-parliamentary.

These results suggest that stronger, bigger and parties within parliament are more eager to provide interactive relationship with voters and citizens and to enable information delivery to public.

Table 4. E-democracy Techniques Comparison Among Single Registered Political Parties

\begin{tabular}{|c|c|c|c|c|c|c|c|c|}
\hline Political party & $\begin{array}{c}\mathrm{e}- \\
\text { access }\end{array}$ & e-poll & $\begin{array}{c}\mathrm{e}- \\
\text { petition }\end{array}$ & e-forum & $\begin{array}{c}\text { e- } \\
\text { consult } \\
\text { ation } \\
\end{array}$ & $\begin{array}{c}\text { e- } \\
\text { election }\end{array}$ & $\begin{array}{c}\text { e- } \\
\text { referen } \\
\text { dum }\end{array}$ & N/A \\
\hline $\begin{array}{l}\text { 1. Active Slovenia } \\
\text { (AS) }\end{array}$ & $x$ & $\mathrm{x}$ & & & & & & \\
\hline 2. Association for & & & & & & & & \\
\hline $\begin{array}{l}\text { Primorska } \\
\text { Region (ZZP) }\end{array}$ & $\mathrm{x}$ & & & & & & & \\
\hline $\begin{array}{l}\text { 3. Association of } \\
\text { Independents of } \\
\text { Slovenia (ZNS) }\end{array}$ & $x$ & & & & & & & \\
\hline 4. Democratic & & & & & & & & \\
\hline $\begin{array}{l}\text { Pensioners } \\
\text { Party (DESUS) }\end{array}$ & $x$ & $\mathrm{x}$ & & & & & & \\
\hline 5. Slovenian & & & & & & & & \\
\hline $\begin{array}{l}\text { Democrats } \\
\text { (DS) }\end{array}$ & $x$ & & & & & & & \\
\hline $\begin{array}{l}\text { 6. Voice of } \\
\text { Women (GZS) }\end{array}$ & $x$ & & & & & & & \\
\hline 7. Communist & & & & & & & & \\
\hline $\begin{array}{l}\text { Party of } \\
\text { Slovenia (KPS) }\end{array}$ & $\mathrm{x}$ & & & & & & & \\
\hline 8. Liberal & & & & & & & & \\
\hline $\begin{array}{l}\text { Democracy of } \\
\text { Slovenia (LDS) }\end{array}$ & $\mathrm{x}$ & $\mathrm{x}$ & & & & & & \\
\hline
\end{tabular}


9. New

Democracy of

$\mathbf{x}$

Slovenia (NDS)

10. New Slovenia -

Christian

People's Party

X

$\mathrm{x}$

(NSi)

11. New Party

(NS)

12. Progressive party (PS)

13. Republicans of Slovenia (RS)

14. Slovenia is ours (SJN)

15. Slovenian

National Party

(SNS)

16. Slovenian

Pcople's Party

X

$\mathrm{x}$

X

(SLS)

17. Slovenian

Democratic

x

$\mathrm{x}$

x

Party (SDS)

18. Ecological

Movement of

x

X

$\mathrm{x}$

Slovenia (SEG

19. Youth Party of

Slovenia

$\mathrm{x}$

$\mathrm{x}$

(SMS)

20. Slovenian

Nation's Party

X

(SSN)

21. United List of

Social

Democrats

$\mathrm{x}$

(ZLDS)

22. Greens of

Slovenia (ZS)

$\mathrm{x}$

\section{Results}

Although providing basic theoretical framework and limited empirical data collection, answering research assumptions raised in this paper seems rather difficult. The 
general research assumption whether web sites of Slovenian political parties are designed according to the elitist-competitive model of democracy, is supported by empirical findings. In general, web sites provided only three distinctive e-democracy techniques: e-access (information delivery), e-poll (public opinion measurement) and e-forum (creating and expressing political standings). According to theoretical framework and analytical model, those applications present central elements of competitive-elitist model of democracy. E-voting was the only one application, suitable to this model, which was not identified during web sites analysis.

Second assumption, whether web sites more often employ one way political information and promotion flows than interactive e-democracy techniques is also confirmed by empirical findings. E-access and e-poll applications present, according by frequency, most common communication flow between Slovenian political parties web sites and Internet users. Those applications, supplemented by e-questionnaires and e-comments options represent typical one-way communication flow which dominates political party's web sphere. On the other hand, web sites also employ substantive amount of various interactive communication flows such as eforums and chat rooms. Although such applications do provide some degree of twoway communication between Internet users and political parties, but are limited to informal, non-biding and trivial conversation and opinion exchange among Internet users itself. As a result, interactivity on web sites does not support public participation in deliberative decision-making, but rather in sharing already established political standings among Internet users.

The last assumption whether Slovenian political parties web sites contribute to reduction of the democratic deficit of representative democracy in Slovenia, can is both supported and rejected. Firstly, it can be supported because important part of democratic deficit of representative democracy, especially its competitive-elitist and legalist perception as defined by Van Dijk (1996), consists of information deficit that causes transparency in efficiency problems of a current political system. All consulted web sites provided variety of information concerning policy and legislative process within parliament, parties activities and work, positions and standing to certain issues, political programmes etc. Since extensive information delivery enables voters and citizens to form and express public opinion, to receive insight in political arena and consequently control and evaluate their political representatives ${ }^{6}$, it safe to say that web sites contribute to reduction of democratic deficit by enabling e-access technique. By enabling e-poll and e-forum applications, web sites also contribute to formulating and expressing public opinion on public issues which can help reducing democratic deficit in terms of citizen's political socialisation and education. As already mentioned, since political parties do not use those applications in deliberative and discursive way, further democratic effect is questionable. Secondly, the assumption that Slovenian political parties web sites contribute to reduction of the democratic deficit can be rejected, because they do not support any e-consultation or e-petition techniques. In theory, important part of representative democratic deficit consist of participation deficit [Becker and Slaton, 2000] which indicates lack of communication channels that enable citizens to directly influence political decisions such as legislation and policy documents (strategies, programmes, plans). At 
the level of political party's role in representative democracy this would mean that citizens take part in decision-making concerning party's legislation and policy proposals which are then decided in parliament. As already mentioned, no Slovenian political party's web site provided any e-democracy technique that would support deliberative electronic participation such as e-consultation and e-petition ${ }^{7}$, which are according to Trechsel (2002: 47-49) designed for increasing public participation in certain policy filed by initiating or responding on policy and legislative proposals. Since party's web sites currently provide only simple and traditional techniques for gathering public opinion (e-polls, e-questionnaires, e-comments etc.), Slovenian citizens can not directly influence party politics thorough moderated and continual econsultations. As result web sites do not contribute to reduction of democratic deficit in terms of participatory democracy.

\section{Conclusion}

E-democracy techniques analysis on Slovenian political party's web sites shows, that in terms of reducing democratic deficit, promoting public participation and deliberative democracy development in Slovenia, there are still a lot of opportunities that remain unchallenged ${ }^{8}$. Electronic communication flows between parties web sites and Slovenian citizens are designed according to competitive-elitist model of democracy as defined by Van Dijk, (1996: 48), which favors one-way information delivery on political issues, political campaigns and expressing political standings. At the application end, this model clearly favors e-access, e-poll and e-forum techniques that dominate party's web sites. Political communication between citizens and Slovenian political parties is based on using the Internet for election and information campaigns, political mobilization and persuasion, promotion, debating and foremost as efficient tool of public relations. Most of the political party's information provided is one-way, top-down, party to voter rather than two-way interactive communication. By employing limited selection of e-democracy techniques on their web sites, Slovenian political parties fail to play a leading role in the diffusion of new technologies for participatory ends and providing direction for civic political action in order to implement idea of digital democracy. Since their web sites do not support e-consultation and e-petition tools, they also fail to involve Internet users in deliberative and interactive participation on policy and law proposals. Parties do not tend to rally widen participation extensively, nor do established electronic channels necessarily empower ordinary citizens since such channels rarely play a formal role in decisionmaking and for a large part are controlled by parties elites. They tend to use Internet for involving voters in ways that are largely beneficial to the parties' own promotion. As such citizens are reduced on passive consummation of political information, rather than creating own political standings and applying them in political decisions. At the end, party's web sites do not favor active citizen ideal. As labeled by Becker and Slaton (2000: 140): "They are, in our view, cyberpolitics - as-usual. And since politics-as-usual, in our view, is dis-empowering to say the least, emulating it on the Web does not change anything for the better. Actually, such web sites are akin to 
public relations-they aim to shore up, reinforce, and cyber legitimize a system that specializes in creation the "necessary illusions « so vital to the status quo."

Regarding those assumptions, further steps should be reconsidered when upgrading web sites in order to enrich public debate on political issues and to allow citizens to directly participate in democratic decision-making. Firstly, it is necessary to adopt conceptual shift in designing web sites. They should be designed according to models of democracy, which favor greater and wider public participation. At the structural level, conceptual shift should result in adopting participatory model of democracy according to Van Dijk's typology and model of associative democracy as suggested by Perczynski (2001). Consequently, e-democracy tools deriving from participatory model, e-consultation and e-poll, should be applied on web sites. Secondly, from procedural level, interactive part of web sites communication (eforums and e-consultations) should be grounded in deliberative democracy as suggested by Fishkin (2000), which provides standards for focused, moderated and creative decision-making on political issues. Adopting such conceptual changes in political party's web sites design would contribute to more transparent, informed, deliberative, democratic and legitimate decisions within representative democracy and helping to reduce participatory democratic deficit. But on the other hand it would also shift the balance of power within parties from higher levels to those at the button of decision-making. Thirdly, for this reason it is necessary to promote successful practices of e-democracy cases in Slovenia, which would consequently lead to much needed change in political culture. Only when recognizing advantages from participatory usage of Internet for democracy development and consequently recognizing their own benefits, political parties will start to redesign their web sites, which would lead to further diminishing of democratic deficit in Slovenia.

Current Slovenian political party's web sites present proper foundation for suggested conceptual upgrade. In order to result from upgrade, it is important that legal institutions and policy-making practices adopt e-participation as legitimate and legal part of decision-making procedure. This can not be achieved without changes in political culture and governing style, upon which representative democracy in Slovenia is currently based. As noted by Andrej A. Luksic (2003: 26): "Using current efforts, Slovenia achieved informatization level of information society. But now process of its 'communicatization' awaits, as next level in development of information society. Supported by 'communicatization', the process of democratization of democracy can yet begin."

\section{References}

1. Becker, Theodore Lewis / Slaton, Christa Daryl (2000) The Future of Teledemocracy. Westport (Conn.), London: Praeger.

2. Bellamy, C. / Taylor, John A. (1998) Governing in the information age. Buckingham.

3. Bernik, Ivan / Uhan, Samo (2002) Koliko nezadovoljstva lahko prenese mlada demokracija? V N. Tos / I. Bernik (ur.) Demokracija v Slovenij, 113-138. Ljubljana: FDV, IDV, Center za raziskovanje javnega mnenja in mnozicnih komunikacij. 
4. Center za raziskave javnega mnenja in mnozicnih komunikacij (CJMMK): Slovenian public oppinion-Politbarometer (May 2004).

[URL:http://e-uprava.gov.si/ispo/politbarometer/prikaz.ispo?vprKey=120\&pregled=0], (25.5.2004).

5. Coleman, S. (2004) Connecting Parliament to the Pubic via the Internet. Information, Communication \& Society. Vol. 7, No. 1, pp. 1-22.

6. Delakorda, Simon (2003) Elektronska demokracija $\vee$ refleksiji izbranih politoloskih kategorij: politicne participacije, politicne moci in politicne akcije. In Andrej A. Luksic / Tanja Oblak (ed.), S poti v digitalno demokracijo, 87-104. Ljubljana: Fakulteta za druzbene vede.

7. Della Porta, D. (2003) Temelji politicne znanosti. Ljubljana: Sophia.

8. Donk, Wim van de (2004) Cyberprotest: new media, citizens, and social movements. London, New York: Routledge.

9. Fishkin, James (2000) Virtual Democratic Possibilities: Prospects for Internet Democracy, Department of Government, University of Texas at Austin.

[URL:http://cdd.stanford.edu/research/papers/brazil_paper.pdf], (5.5.2004).

10. Franz, Damjan (2002) Theoretical and Empirical Aspects of Digital Democracy with the Focus on Slovenia. Presented at the Euricom Colloquium: Electronic Networks \& Democracy, 9-12 October 2002.

11. Gibson, Rachel Kay / Römmele, Andrea / Ward, Stephen J. (2004) Electronic democracy: mobilisation, organisation and participation via new ICTs. London, New York: Routledge.

12. Grossman, Lawrence K. (1995): The electronic republic: reshaping democracy in the information age. New York: Viking.

13. Hagen, Martin (1996) A Road to Electronic Democracy? Politische Theorie, Politik und der Information Superhighway in den USA in Hans J. Kleinsteuber (ur.) 1996: Der Information Superhighway. Opladen: Westdeutscher Verlag, str. 63-85.

[URL:http://www.uni-giessen.de/fb03/vinci/labore/netz/hag_en.htm], (15.5.2004).

14. Hague, Barry N. / Loader, Brian D. (2001). Digital democracy: discourse and decision making in the Information Age. London, New York: Routledge.

15. Luksic, Andrej (2003) Hermesovi obrazi demokracije. In Andrej A. Luksic/ Tanja Oblak (ed.), S poti v digitalno demokracijo, 11-33. Ljubljana: Fakulteta za druzbene vede.

16. Makarovic, Matej (2002) Politicna participacija v desetletju demokratizacije. V N. Tos / I. Bernik (ur.) Demokracija v Sloveniji, 65-87. Ljubljana: FDV, IDV, Center za raziskovanje javnega mnenja in mnozicnih komunikacij.

17. Neumann, Franz (1950) Politicka znanost u demokraciji. Treci program, st. 64 (1985), str. 363-378.

18. Nixon, P., / H. Johansson (2001). Transparency through Technology: The Internet and Political Parties. In B. Hague / B. Loader (ed.), Digital democracy: discourse and decision making in the Information Age, 135-153. London, New York: Routledge.

19. Norris, P. (2003) Preaching to the Converted: Pluralism, Participation and Party Web Sites. Party Politics 9(1): 21-45.

20. Oblak, Tanja (2003) Izzivi e-demokracije. Ljubljana: Fakulteta za druzbene vede. 
21. Offe, Claus (1985) Druzbena moc in politicna oblast: protislovja kapitalisticne demokracije: razprave o politicni sociologiji poznega kapitalizma. Delavska enotnost. Ljubljana.

22. Perczynski P. (2001) Associo-deliberative democracy and qualitative participation. In Hirst, Paul / Bader, Veit-Michael (ed.), Associative democracy: The Real Third Way, 7184. London, Portland (OR): F. Cass.

23. Van Dijk, Jan A.G.M, (1996) Models of Democracy - Behind the Design and Use of New Media in Politics. Javnost 3(1), 43-56.

24. Van Selm, M., Jankowski N.W., Tsaliki, L. (2001). Political Parties Online: An Examination of Electronic Democracy on Three Dutch Political Party Web Sites. Paper presented at Euricom Colloquium: E-Networks \& Democratic Life (Piran, Slovenia).

25. Trechsel, Alexandre H. (et al.) (2003) Evaluation of the use of new technologies in order to facilitate democracy in Europe: e-democratizing the parliaments and parties of Europe. Geneve: Research and Documentation Centre on Direct Democracy.

26. Tsagarousianou, Roza / Tambini, Damian / Bryan, Cathy (1998) Cyberdemocracy: technology, cities and civic networks. London, New York: Routledge.

27. Vreg, France (2001) Globalizacija in elektronska demokracija. Teorija in praksa 38 (1), 5-28.

28. Vintar, Mirko / Decman, Mitja / Kunstelj, Mateja (1999) Telematics and the Service of Democracy: The Slovenian Parliament and Other Slovenian Public Institutions on the Internet. Parliamentary Affairs 52, 3, 451-463.

29. Vodopivec, Franc/Ursic, Sonja / Franko, Maja (2002) Vec neposredne demokracije v Sloveniji - da ali ne. Novi trendi v javnem menedzmentu: predavanje 17. aprila 2002: zbornik referatov in razprav. Ljubljana: Drzavni svet Republike Slovenije.

30. Ward, S., Gibson, R. K., and Lusoli, W. (2003) Participation and Mobilisation Online: Hype, Hope and Reality. Parliamentary Affairs 56(3): 652-668.

\section{Appendix}

A list of identified political parties web sites:

a) Parliamentary ${ }^{9}$ (consulted on $15^{\text {th }}-18^{\text {th }}$ of March 2004 and supplemented on $27^{\text {th }}$ of July 2004)

http://www.Ids.si/ Liberalna demokracija Slovenije (LDS); Liberal Democracy of Slovenia http://www.zlsd.si/ Zdruzena lista socialnih demokratov (ZLSD); United List of Social

Democrats

http://www.sls.si/ Slovenska ljudska stranka (SLS); Slovenian People's Party

http://www.desus.si/ Demokraticna stranka upokojencev Slovenije (DeSUS); Democratic

Pensioners Party

http://www.sds.si/ Slovenska demokratska stranka (SDS); Slovenian Democratic Party http://www.sns.si/ Slovenska nacionalna stranka (SNS); Slovenian National Party http://www.nsi.si/ Nova Slovenija - Krscanska ljudska stranka (NSi); New Slovenia - Christian People's Party 
http://www.sms.si/ Stranka mladih Slovenije (SMS); Youth Party of Slovenia

b) Non-parliamentary (consulted $15^{\text {th }}-18^{\text {th }}$ of March 2004 and supplemented on $27^{\text {th }}$ of July 2004)

http://www.zeleni.si/ Zeleni Slovenije (ZS); Greens of Slovenia http://www.sgn.net/ zoranp/ds/stranka.htm Demokratska stranka Slovenije (DS); Slovenian Democrats

http://www.glaszensk.si/ Glas zensk Slovenije (GZS); Voice of Women http://users.volja.net/mrmilan/kps.htm Komunisticna partija Slovenije (KPS); Communist Party of Slovenia

http://www.republikanci.si/ Republikanci Slovenije (RS); Republicans of Slovenia http://www.seg.si/slo/ Stranka ekoloskih gibanj Slovenije (SEG); Ecological Movement of

Slovenia

http://zzpkp.naspletu.com/ Zveza za Primorsko (ZZP); Association for Primorska Region

http://freeweb.siol.net/insignij/firme/ssn/program.htm Stranka Slovenskega naroda (SSN);

Slovenian Nation's Party

http://www.nds.si/nds.php Nova demokracija Slovenije (NDS); New Democracy of Slovenia http://www.aktivnaslovenija.si/ Aktivna Slovenija (AS); Active Slovenia

$\mathrm{http}: / / w w w . s j n . s i /$ Slovenija je nasa (SJN); Slovenia is ours

http://www.zveza-zns.si/ Zveza neodvisnih Slovenije (ZNS); Association of Independents of

Slovenia

http://www.progresivna-stranka.si/ Progresivna stranka (PS); Progressive party

http://www.nova-stranka.si/ Nova stranka (NS); New Party (web link is not working)

1 It is important to realise that these models are theoretical constructions. In fact they are ideal types. In the reality of political systems and views several of them can be combined, often in contradictory ways (Van Dijk, 1996: 46)

2 Every political system of parliamentary democracy also has non-registered political parties (usually minor, non-influential, publicly unknown and locally based). Since official data on their number and names does not exist in Slovenia we excluded them from empirical research.

3 Ministry of Internal Affairs of Republic of Slovenia (MNZ RS):

http://www.mnz.si/si/urupnot.php?men=menu/M1324.inc\&tekst=Seznam\%20politi_nih\%20strank\&d at $=$ upl/uru pnot/stranke.htm

4 As noted during research, those e-poll applications are usually design in order to get already formed public opinion standing (similar to TV or news papers polls) and not to identify public opinion that derives from deliberative public debate or consultation.

5 As noted, those forums were not design in order to enable focused, moderated and deliberated public debate on certain political issue which would result in qualitive public oppinion formation. Contrary to discursive usage of this e-democracy tool, political parties e-forums mainly are understood as public place for expresing individual and plain political positions, attacking political opponents, advertising political ideologies and engaging in fruitless personal debates.

6 At this point we are not discussing friendlines of information delivery and quality of information itself. 
7 In some cases parties web sites provided sort of possibilities for citizens to directly express and consult their standings with political parties and their leaders but they were rather informal, non deliberative and non binding. For example governmental party LDS (Liberal Democracy of Slovenia) enabled citizens to fulfill e-questionnaire on priorities concerning future development of Slovenia and provided informal chat room application between party leaders and citizens http://www.Ids.si/kiosk.cp2 (consulted on 27th of July 2004). Parliamentary parties such as SLS (Slovenian People's Party), NSi (New Slovenia Christian People's Party), SNS (Slovenian National Party) and ZLDS (United List of Social Democrats) enabled citizens to publicly comment news, statement and articles provided on parties web sites. Parliamentary opposition party SDS (Slovenian Democratic Party) also provided possibility to comment members of parliament statements in documents from parliamentary sessions http://seja.sds.si/ (consulted on $27^{\text {th }}$ of July 2004).

8 See also Franz (2003)

9 http://www.uvi.si/slo/slovenija/naslovi-povezave/stranke/ List of Slovenian parliamentary political parties web sites (consulted on $15^{\text {th }}$ of March 2004) 